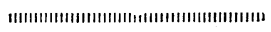

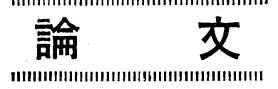

\title{
低炭素鋼の応力休止を与えた場合のクリープ破断*
}

\author{
小寺沢良一林 野々村泰三***
}

\section{Creep Rupture Test of a Low Carbon Steel under Interrupted Loading}

by

\author{
Ryoichi Koterazawa and Taizo Nonomura \\ (Kyoto University) (Doshisha University)
}

\begin{abstract}
Creep rupture tests under interrupted loading were carried out with a low carbon steel at a temperature of $450^{\circ} \mathrm{C}$. The load was applied once a day for the period of one tenth of rupture under continuous loading. Transient increase of creep rate was observed at the beginning of every loading interval through all stages (the 1st, 2 nd and $3 \mathrm{rd}$ stages) of creep. As the results of this increase of strain rate, the rupture life under the interrupted loading was somewhat less than under the continuous loading, although the difference is practically negligible except when it is under high stress level. The increase of creep rate seems to result from the softening of the material during the unloading interval rather than recovery. (Received June 7, 1960)
\end{abstract}

\section{1. 緒言}

高温において使用される機械部分の設計に際して， その材料のクリープ強度を知ることが重要なことは云 うを待たないところであって, 以前より一定荷重の下 における静クリープ試験が盛んに行なわれ，多くの実 験結果が報告されている。しかし，実際に機械部分の 受ける荷重は運転休止, 負荷の変動などのためときに よって異なった值を持つのが一般である。これに関連 して, 応力休止を与えた場合のクリープ現象について は, 亜鉛, 低炭素鋼その他について研究が行なわれ， 応力休止中に生ずる回復のために, 再負荷直後におい て，休止直前に比べてクリープ速度がかなり大きく， そのため若干のひずみの増加を生ずることが報告され ている.しかし、これらの研究は主として第 1 期およ び第 2 期クリープ段階におけるもので，このようなひ ずみの増加が以後の変形にどのような影響を与え, 破 断寿命にいかなる影響を与えるかは明らかでない．こ こではこの意味から低炭素鋼について, 応力休止を与 えた場合のクリープ現象を破断に至るまでの全過程に ついて検討せんとするものである.

\section{2. 試験装置および試験材料}

試験機は NPL 型静引張クリープ試験機であってて, レバー比 $20: 1$ の単一レバー式で, 容量は 3 ton であ る. 加熱炬はニクロム線を発熱体とする電気炉で，加

\footnotetext{
* 原稿受付 昭和 35 年 6 月 7 日

** 正員 京部大学工学部

**** 正員 同志社大学工学部
}

熱巻線を上中下に 3 分割し，各独立に端子電圧を調整 可能である，温度調節装置は Prosser 方式で，温度測 定はアルメルクロメル熱電対と電位差計式温度計なら びに自動温度記録計によっている，以上により試験片 温度の時間的変動と標点間における温度差を試験温度 $450^{\circ} \mathrm{C}$ において $\pm 1^{\circ} \mathrm{C}$ 以内に押さえている.

試験片は直径 $10 \mathrm{~mm}$ 標点距離 $100 \mathrm{~mm}$ のもので, その形状を Fig. 1 に示す. 伸び測定は図示のつばに 伸び測定用取出棒を取り付け，炣外においてダイアル ゲージ $(1 / 100 \mathrm{~mm})$ で読み取る方法によっている.

試験材料は $0.16 \%$ 炭素鋼で, その化学成分, 熱処 理条件および常温における機栈的性質を Table 1, Table 2 に示す.

\section{3. 試 験 結 果}

試験条件および試験結果(破断時間, 伸び, 絞り)を Table 3 に総括する. 表中, 休止を与えた場合の破断

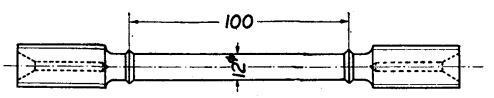

Fig. 1 Test specimen

Table 1 Chemical composition and condition of heat treatment of test material

\begin{tabular}{c|c|c|c|c|c|c|c|c}
\hline $\begin{array}{c}\text { Com- } \\
\text { position }\end{array}$ & $\mathrm{C}$ & $\mathrm{Si}$ & $\mathrm{Mn}$ & $\mathrm{P}$ & $\mathrm{S}$ & $\mathrm{Ni}$ & $\mathrm{Cr}$ & $\mathrm{Cu}$ \\
\hline$(\%)$ & 0.16 & 0.25 & 0.41 & 0.013 & 0.014 & 0.05 & 0.08 & 0.15 \\
\hline
\end{tabular}

昭和 35 年 9 月 
時間としては休止時間を除いた破断までの負荷時間を 示している。

試験温度は低炭素鋼について，第 1 期クリープにお いて応力休止を与えた場合について行なわれている実 験と同一の $450^{\circ} \mathrm{C}$ とし, Table 3 に示した各応力にお

Table 2 Mechanical properties at room temperature

\begin{tabular}{c|c|c|c}
\hline $\begin{array}{c}\text { Yield point } \\
\left(\mathrm{kg} / \mathrm{mm}^{2}\right)\end{array}$ & $\begin{array}{c}\text { Tensile } \\
\text { strength } \\
\left(\mathrm{kg} / \mathrm{mm}^{2}\right)\end{array}$ & $\begin{array}{c}\text { Elongation } \\
(\%)\end{array}$ & $\begin{array}{c}\text { Reduction of } \\
\text { area }(\%)\end{array}$ \\
\hline $33 \cdot 3$ & $42 \cdot 7$ & $42 \cdot 0$ & $71 \cdot 1$ \\
\hline
\end{tabular}

Table 3 Test conditions and results Test temperature $450^{\circ} \mathrm{C}$

\begin{tabular}{|c|c|c|c|c|c|c|}
\hline \multirow{2}{*}{ 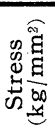 } & \multicolumn{2}{|c|}{ Time to rupture } & \multicolumn{2}{|c|}{$\begin{array}{l}\text { Elongation of } \\
\text { ruptured } \\
\text { specimen }(\%)\end{array}$} & \multicolumn{2}{|c|}{$\begin{array}{l}\text { Reduction of } \\
\text { area }(\%)\end{array}$} \\
\hline & $\begin{array}{l}\text { Continu- } \\
\text { ous }\end{array}$ & $\begin{array}{l}\text { With } \\
\text { rests }\end{array}$ & $\begin{array}{c}\text { Continu- } \\
\text { ous }\end{array}$ & $\begin{array}{l}\text { With } \\
\text { rests }\end{array}$ & $\begin{array}{c}\text { Continu- } \\
\text { ous }\end{array}$ & $\begin{array}{l}\text { With } \\
\text { rests }\end{array}$ \\
\hline 20 & $75 \cdot 8$ & $81 \cdot 5$ & 51.0 & $53 \cdot 5$ & $73 \cdot 4$ & $74 \cdot 2$ \\
\hline 21 & $37 \cdot 5$ & $32 \cdot 8$ & 50.0 & 60.4 & $75 \cdot 4$ & 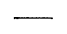 \\
\hline 23 & 8.0 & $8 \cdot 1$ & 50.0 & $54 \cdot 3$ & $75 \cdot 2$ & $73 \cdot 7$ \\
\hline 24 & $4 \cdot 4$ & $3 \cdot 9$ & $50 \cdot 6$ & $59 \cdot 5$ & $76 \cdot 9$ & $77 \cdot 7$ \\
\hline 25 & $2 \cdot 7$ & 1.7 & $56 \cdot 0$ & $56 \cdot 8$ & $78 \cdot 3$ & $76 \cdot 2$ \\
\hline
\end{tabular}

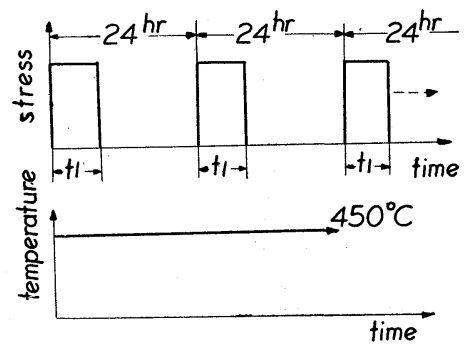

$\mathrm{t}_{c}:$ rupture time under continuous loading

$$
t_{l} \cong \frac{t_{c}}{10}
$$

Fig. 2 Program of load interruption

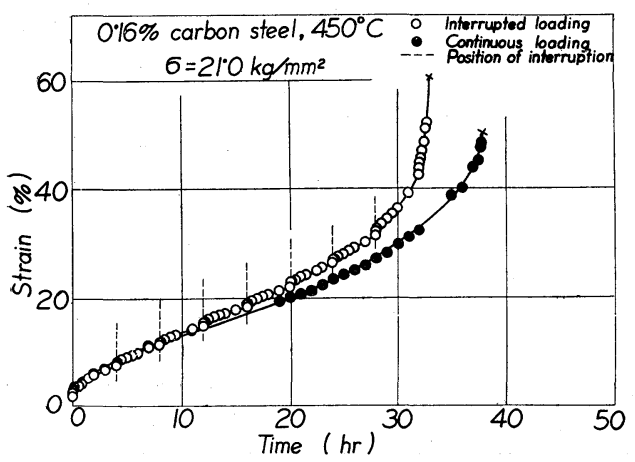

Fig. 3 Creep curves under interrupted and continuous loadings $\left(\sigma=21 \cdot 0 \mathrm{~kg} / \mathrm{mm}^{2}\right)$
いて休止を与えた場合と与えない場合の試験を破断に 至るまで行なっている，応力休止のプログラムはFig. 2 に示すとおりで，休止を与えない場合の破断時間の 約 $1 / 10$ の時間だけの負荷を 1 日 1 回与えている.

Fig. 3〜Fig. 5 に休止を与えた場合と与えない場合 のクリープ曲線の比較例を示す。図中, 横軸の時間は, 休止を与えた場合には休止時間を除いた負荷時間をと って示している. また, Fig. 6 は Table 1 の結果を 負荷応力と破断までの負荷時間の関係を示す線図とし

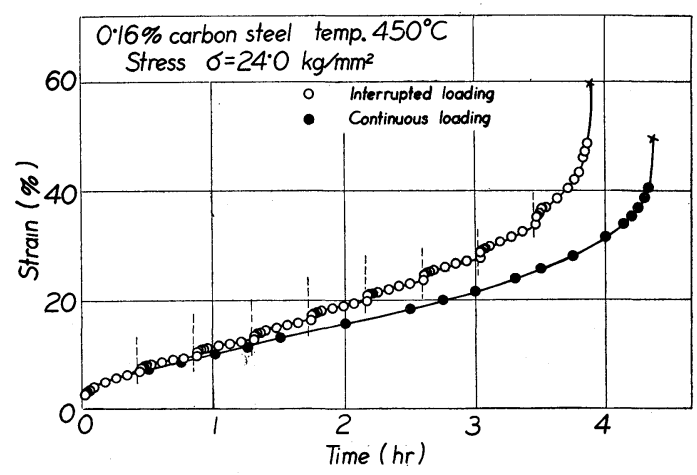

Fig. 4 Creep curves under interrupted and continuous loadings $\left(\sigma=24 \cdot 0 \mathrm{~kg} / \mathrm{mm}^{2}\right)$

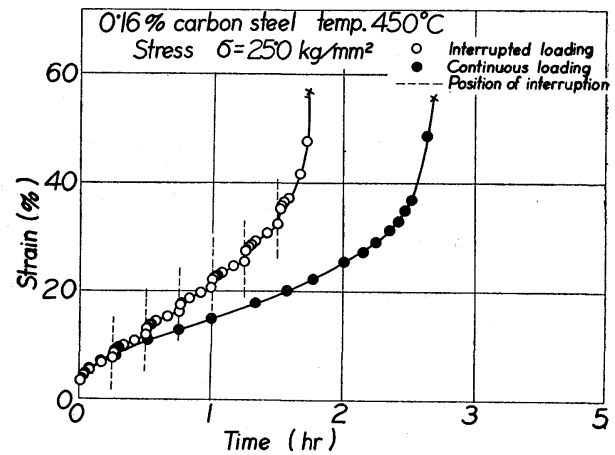

Fig. 5 Creep curves under interrupted and continuous loadings $\left(\sigma=25^{*} 0 \mathrm{~kg} / \mathrm{mm}^{2}\right)$

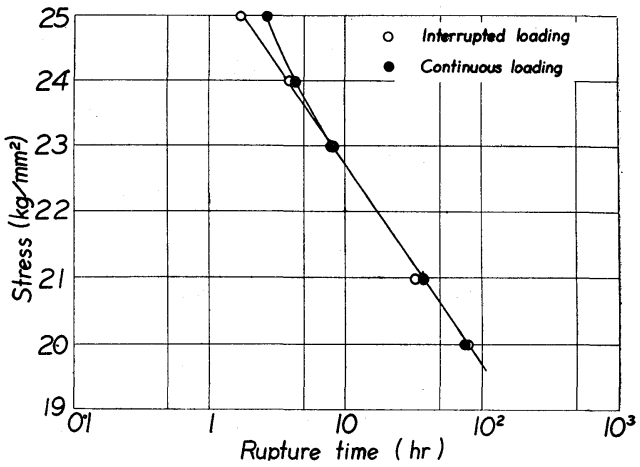

Fig. 6 Stress-rupture time curves for interrupted and continuous loadings

「材料試験」第 9 巻第 84 号 
て表わしたものである. Fig. 3〜Fig. 5 より明らかな ように, 既に報告されている試験結果と同様に, 休止 を与えた場合においては再負荷直後の短時間の間, ひ ずみ速度の増加を生じていることが認められ，この間 に生じた増加ひずみのため, 全ひずみは同一時間の休 止を与えない場合のクリープひずみに比べてやや大と なっている。この傾向は応力の大きい場合ほど著しい. これらの傾向は第 2 期および第 3 期クリープ段階にお いてもほぼ同様であって，その結果として休止を与え た場合の破断までの負荷時間は与えない場合に比べて やや小さいことが認められる.Fig. 6 に示すようにこ の差異は大きいものではなく, 応力が大きい場合のほ かはほとんど実験結果のばらつきの程度で実際問題と しては無視しうるものであるが, 再負荷值後のひずみ 増加の大きい高応力の下で差の著しいことは, 再負荷 後の增加ひずみが破断寿命の減少と密接に関連してい ることを示している. Table 3 中に示したように, 破 断伸びについては休止を与えた場合のほうが与えない 場合よりわずかに大きい傾向が認められる，既に述べ たように再負荷後の増加ひずみは応力の高いほど大で ある。この増加ひずみが破断伸びの増加をもたらした とすれば, 破断伸びも応力が高いほど大となることが 予想されるが，実験結果は必ずしもそのような傾向を 示していない.すなわち增加ひずみは必ずしも破断伸 びを増加せしめるものではなく，増加ひずみが大きい 場合に，それに相当するだけ破断伸びが大きくならな いため寿命の減小を生ずる結果となっている，絞りに ついては休止の影響の差は認められない。

\section{4. 考察}

前節で述べたように，低炭素鋼については応力休止 は破断寿命に大きい影響は与えないが，詳細にみると 再負荷直後に生じた増加ひずみが破断寿命と密接に関 連していて，これを減少させる傾向を持つことが認め られる.この増加ひずみの生ずる理由としては, 従来 休止中における回復が考えられているようである。も し，この “回復”によって，その材料が処女材の状態 へ近づくものならば，休止を与えることにより破断寿 命は増加すべきであるが，本奏験結果ではそのような 傾向はほとんど認められない.これは，ここに起こっ ている“回復”が文字どおりの意味のものでなく，む しろ軟化と呼ぶべきものであると考えられる。すなわ ち, 転位論的にみれば, クリープ過程は転位の集積に よる硬化と上昇その他に基づ〈転位の再配列による軟 化の交代であるとされているが，休止中に生ずる転位 の再配列も初期状態一向かっての再配列ではなく，休 止を与えず連続負荷した場合に負荷応力の作用の下で 進行すべき熱摇動による転位の上畀などが，休止中に 熱摇動の作用のみにより既に進行しているものとみる
べきである，云いかえれば，材料の状態としては初期 状態への回復ではなく, 更に進んだ状態への移行であ るとみられる。

以上は破断寿命に対する増加ひずみの作用であるが， 変形に対しても同様のことが認められる。すなわち, クリープ過程中におけるひずみとひずみ速度の関係を 示す線図を描くと Fig. 7, Fig. 8 のようになる。これ によると, 休止を与えた場合の結果は再負荷後の過渡 的な期間を除いては休止を与えない場合の結果とほぼ 一致している。横軸のひずみは増加ひずみをも含めた ものであるから，この結果はある応力の下におけるひ ずみ速度すなわち变形抵抗が休止の有無にかかわらず, そのときの全塑性ひずみによって決定されることを示

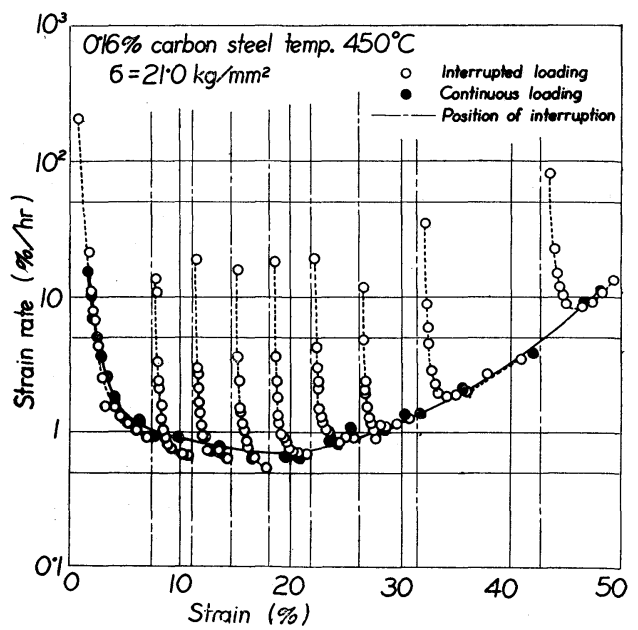

Fig. 7 Relation between strain and strain rate under interrupted and continuous loadings $\left(\sigma=21 \cdot 0 \mathrm{~kg} / \mathrm{mm}^{2}\right)$

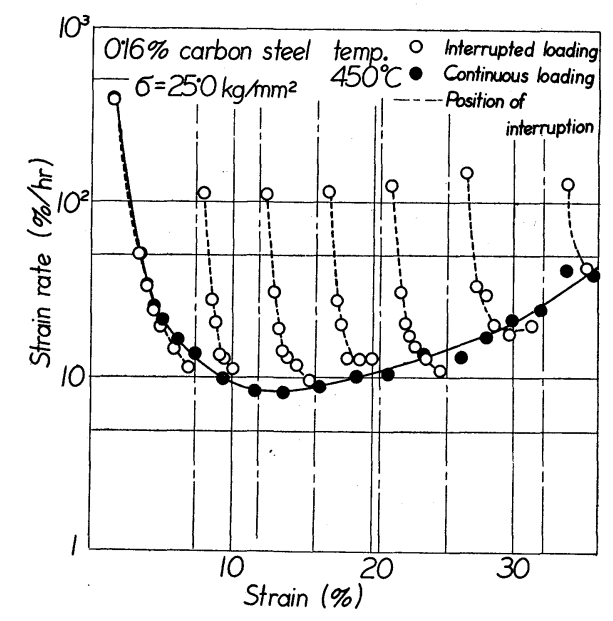

Fig. 8 Relation between strain and strain rate under interrupted and continuous loadings $\left(\sigma=25 \cdot 0 \mathrm{~kg} / \mathrm{mm}^{2}\right)$ 
している。云いかえれば増加ひずみをも含めた全ひず みによってその材料の状態が表わされるもので, この ことは増加ひずみが全塑性ひずみの他の部分と全く同 様にその材料の状態進行に寄与することを意味してい る。

\section{5. 結言}

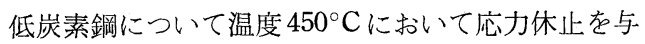
えた場合のクリープ破断試験を行なった．その結果を 要約すれば次のとおりである。

（1）応力休止を与えた場合, 再負荷直後短時間の 間, 過渡的なひずみ速度の増加が認められ, 増加ひず みを生じた。この増加ひずみは応力の大きいほど大き い.これらは第 2 期, 第 3 期クリープ段階においても 第 1 期クリープ段階と同樣に認められる.

（2）応力休止を与えた場合の破断までの負荷時間 は与えない場合と大差ないが，前記増加ひずみに原因 して応力休止を与えない場合よりやや短くなる傾向が 認められた，この傾向は増加ひずみの大きい高応力に おいてより大である。
（3）負荷直後に生ずる増加ひずみは回復よりもむ しろ休止中に進行した材料の軟化により生ずるものと みられ, 以後の材料の状態, すなわち変形抵抗および 破断寿命に及ぼす作用は全塑性ひずみ中の他の部分と 全く同一のもののごとくである.

終りに本研究の計画に際して御指導を睗わった同志 社大学西原利夫教授, 実験に際して御指導を賜わった 京都大学平修二教授, 同志社大学西原正夫教授に対し て深甚の謝意を表し，また，実験に協力された同志社 大学学生和泉滋, 沢田昭穂, 田中大成の諸君に感謝の 意を表する。

\section{参 考 文 献}

1) M. Tanenbaum and.W. Kauzmann, J. Appl. Phys., Vol. 25, p. 451 (1954)

2) 西原, 平, 田中, 大路, 機械学会論文集, 21, 111, 791 796 (昭30)

3) 平, 大路, 榇本, 材料試験, 8, 71, 664 (昭 34)

4) A.J. Kennedy, Proc. Roy. Soc., A 213, p. 492 (1952)

Proc. Phys. Soc., Vol. 68-B, p. 257 (1955)

5) N.F. Mott, Phil. Mag., Vol. 44 p. 724 (1953)

\section{外国交献紹介}

金属材料

\section{時間一温度パラメーターの加速クリープ破断試験へ}

の適用について (The Application of Time-Temperature Parameter to Accelerated Creep Rupture Testing) S.S. Manson, G. Succop \& W.F. Brown., Trans., ASM. vol. 51, 911/934 (1959)

本論文は従来のクリープ破断試験結果の簡易決定と して用いられてきた Larson-Miller 法, Manson-Haferd 法, Dorn 法らの研究ではパラメーターの妥当性 を論じることに終止してその推定法の垁際的な評価に ついてあまりかえりみられなかった点を指摘して,よ り少ない実験結果から, いかにして広範囲の応力およ び温度の結果を推定することができるかを奏際的な観 点から論じたものである.すなわち, 上述の方法の各 パラメーターを用いて計算せる isothermal rupture curve (温度を变数とせる design data diagram を 指す）を“17-22A” S フェライト系鋼 ( $\mathrm{Cr}, 1 \cdot 32 \%$,
$\mathrm{Ni}, 0 \cdot 14 \%, \mathrm{C}, 0 \cdot 32 \%, \mathrm{Mo}, 0 \cdot 48 \%$ ) および 16-15-6 オーステナイト系鋼 $(\mathrm{Cr}, 16 \cdot 16 \%, \mathrm{Ni}, 15 \cdot 60 \%$ ， Mo, 6.10\%，C，0.67\%）について作成し，これらは master creep curve を作るに必要な長時間試験結果 の約 2 倍の時間まで外そうしうることを指摘している。 まえ，この際 Manson-Haferd 法の直線性パラメ一タ. 一を用いて作成せる isothermal curve は最もよく実 験結果と一致し, 他のパラメーターによる計算では材 料および応力範囲について誤差を生ずることを明らか にしている．最後に Manson-Haferd 法のパラメータ 一の定数がきわめて短時間に簡易に決定しうることか ら, 本法に基づく isothermal rupture curveはクリ 一プ破断試験時間を大幅に短縮しうるものであること を.上述の 2 種類の銅を例にとって結論づけている.

(大南正瑛) 